\title{
Strategic Trade Policy through the Tax System
}

\author{
Johannes Becker
}

\author{
CESifo Working PAPER No. 3066 \\ CATEgory 1: Public Finance \\ MAY 2010
}
An electronic version of the paper may be downloaded
- from the SSRN website: Www.SSRN.com
- from the RePEc website: Www.RePEc.org
- from the CESifo website: www.CESifo-group.org/wp




\title{
Strategic Trade Policy through the Tax System
}

\begin{abstract}
If conventional instruments of strategic trade policy are unavailable, the system of foreign profit taxation and transfer price guidelines may serve as surrogate policy instruments. In this paper, I consider a model where firms from two countries compete with each other on a third market. I analyze optimal policy choices of the firms' residence countries aiming at strategically manipulating the competitivity of their firms on the third market. I show that, as has recently been claimed, countries prefer the tax exemption system over the tax credit system if transfer prices for headquarter services to the affiliate are close to the headquarter's variable cost and if the third country's tax rate is low (i.e., if there is a large tax differential between both locations within the firm). However, if transfer prices are high and the tax rate in the third market country is sufficiently close to the residence country's tax rate, I show that the tax credit system is an optimal tax policy choice for both countries. From a policy perspective, the view that the tax exemption system is generally the best policy response if domestic firms' competitiveness is a policy goal has to be qualified.
\end{abstract}

JEL-Code: H25, F23.

Keywords: corporate taxation, repatriation tax, transfer pricing.

Johannes Becker
Max Planck Institute for Intellectual Property
Competition and Tax Law
Marstallplatz 1
80539 Munich
Germany
johannes.becker@ip.mpg.de

This version: 20th May 2010

I thank Pascalis Raimondos-Møller and participants at the CESifo Area Conference on Public Sector Economics for very helpful comments. All errors are my own. 


\section{Introduction}

In recent decades, international trade agreements like GATT and supranational institutions like the WTO and the EU have successfully reduced the level of tariffs and production subsidies. Today, if countries want to strategically manipulate the terms of trade of their trade-oriented firms, they have to choose different and subtler means than outright subsidies or tariffs. One potential means to do so is the tax system, especially the set of taxes on multinational firms.

In this paper, I analyze the tax system's scope and potential for strategic trade purposes. I concentrate on two features of the tax system, the regime of foreign profit taxation and transfer price guidelines. The OECD recommends to its members to choose between two regimes of foreign business income taxation, the tax credit system where foreign income is taxed and foreign taxes are credited against the domestic tax liability, and the tax exemption system where foreign income is not taxed by the residence country. As the regime choice is likely to affect the cost of production, it is relevant as a means of indirect strategic trade policy. The same may be true for transfer price guidelines which are required to determine locational income for tax purposes. The choice of transfer price guidelines may serve the goal of efficiency ${ }^{1}$ (not distort production choices) and fairness (ensure a fair share of taxable income in all locations), but it may also be used as an instrument for indirect strategic trade policy. If the two jurisdictions under consideration differ in tax rates, changing the transfer price affects the firm's variable cost and, thus, its competitiveness. Of course, by choosing its set of transfer price guidelines, a country will have to account for the multinational trying to manipulate transfer prices for purpose of tax minimization. ${ }^{2}$

\footnotetext{
${ }^{1}$ The efficiency related objective implies that transfer prices among related parties should not be different from market prices in transactions between unrelated parties. This arm's length principle is, however, often hard to apply, e.g. if such market transactions do not exist, and its efficiency properties crucially depend on the assumption of competitive markets. Moreover, even if an arm's length benchmark exists, its use may lead to distorted incentives within the firm, as Devereux \& Keuschnigg (2009) point out.

${ }^{2}$ Profit shifting by strategic use of transfer prices has been a major research topic in the public finance literature, see e.g. Huizinga \& Laeven (2008) and, for a survey, Devereux (2007). Direct evidence for strategic transfer pricing is given in Bernard and Weiner (1990), Clausing (2003), Overesch (2006). Bernard, Jensen and Schott (2006) document that export prices of U.S. multinationals for intrafirm transactions are significantly lower than prices for the same good sent to an arm's length customer.
} 
The implications of the tax regime choice for the domestic firms' competitiveness has recently been in the focus of a lively debate. ${ }^{3}$ Several countries, among them the United States and the United Kingdom, have reviewed their system of foreign income taxation. The UK has already switched from the tax credit system to the exemption system. The main argument in favour of exemption has been - both in the UK and the US - that a tax on foreign income reduces the competitiveness of domestic firms on foreign markets. For instance, the Office of Tax Policy at the U.S. Treasury Department (2007) states that "U.S. companies increasingly suffer a competitive disadvantage. The U.S. business tax system imposes a burden on on U.S. companies and U.S. workers by (...) burdening U.S. firms as they compete with other firms in foreign markets." (p. i) As a consequence, the Office recommends a switch to the exemption system. ${ }^{4}$ Similarly, the Coalition Agreement (2009) between the three governing parties in Germany states that the government will stick to the exemption system in order to support the competitiveness of German firms. ${ }^{5}$

Transfer price guidelines have been to a lesser extent considered as a means to affect the competitiveness of domestic firms. ${ }^{6}$ However, as this paper argues, the actual level of transfer prices is crucial for the properties of the tax credit

\footnotetext{
${ }^{3}$ Recent contributions include Desai \& Hines (2003, 2004), Devereux (2008), Desai (2009), Hines (2009), Becker \& Fuest (2010). There is an extensive literature on the optimal taxation of foreign profits building on the seminal work by Peggy Musgrave (née Richman, 1963, 1969). For a short overview and discussion, the reader may refer to Mintz \& Tulkens (1996) or Becker (2009).

${ }^{4}$ Before switching to the exemption system, the British Treasury argued: "Business increasingly operates in a global marketplace, where many of the UK's competitors already operate forms of an exemption regime, (...). The Government therefore believes it is now time to consider again the case for exemption." (HM Treasury and HM Revenue and Customs, 2007, p. 13) And Devereux (2008) adds that "imposing a tax on worldwide income will, in general, raise the required pre-tax rate of return, possibly giving the company a competitive disadvantage in foreign markets, and hence reducing the attractiveness of the residence country as a headquarters location." (p. 710)

${ }^{5}$ The Coalition Agreement (2009) says: "We will ensure our companies can remain competitive internationally with our double taxation policies and thus, in principle, adhere to the exemption method on foreign income." (p. 15)

${ }^{6}$ Even when, in 2002, the WTO ruled against the U.S. and forced the country to abolish legal provisions that allowed U.S. multinationals to shift foreign income through tax havens, transfer prices got only little scholarly attention from the competition perspective (see Rosenbaum \& Olson: U.S. Loses Trade Case to Europeans on Offshore Tax Havens, New York Times, January $15,2002)$.
} 
system and exemption system in terms of efficiency and competitiveness. ${ }^{7}$ Thus, the arguments put forward in favor of exemption require some assumptions on the level of transfer prices.

This paper considers the interaction of transfer price policies and the choice of the regime of foreign profit taxation in a strategic setting. It builds on a model in the tradition of Brander \& Spencer (1985) where firms from two countries compete with each other on a third market. ${ }^{8}$ As a crucial difference to Brander \& Spencer (1985), I assume that both firms have production facilities in the third market country which give rise to intra-firm trade. For tax purposes, transfer prices for input goods received from the headquarter are required. ${ }^{9}$ The governments of the residence countries (where the headquarters are) choose a tax on foreign income and - eventually - a transfer price guideline, given the choices of the other country. Then, firms may choose to deviate from the guideline by setting their own, tax minimizing transfer price.

The main results are the following. Firstly, if transfer prices are close to variable costs at the headquarter, the optimal system of foreign income taxation is the exemption system. This result confirms the claims of the exemption proponents, but it has to be qualified because it depends on the actual level of transfer prices. Secondly, if transfer prices for headquarter services to the affiliate are sufficiently high (e.g., to shift a fair amount of taxable income to the headquarter location), the optimal system of foreign profit taxation is the tax credit system. Thirdly, if both countries autonomously choose the transfer price guidelines (and, thus, use them as a means to strategically subsidize production), the exemption system is optimal for low tax rates in the third market and the tax credit system for tax rates close to the residence country's tax rate. Fourthly, if the third country is allowed to choose its tax rate, it will choose a tax rate low enough to trigger an equilibrium where both residence countries choose the exemption system.

\footnotetext{
${ }^{7}$ Becker \& Fuest (2009) provide an example how transfer price guidelines may be used strategically in tax competition. Becker \& Loomer (2009) analyze a country's incentive to use transfer pricing via tax havens in order to improve the country's terms of trade.

${ }^{8}$ Note that this setting differs substantially from the one in Bond \& Samuelson (1989) who also analyse strategic competition in systems of foreign profit taxation.

${ }^{9}$ Note that I do not consider incentive effects of transfer pricing within the firm, as in Holmstrom and Tirole (1991), Elitzur \& Mintz (1996) or Koethenbuerger (2010). I assume that headquarters can perfectly control affiliates.
} 
It is important to note that these results crucially depend on the assumption of an effective lack of suitable policy instruments: the availability of direct subsidies or tariffs is ruled out. As a consequence, each policy choice is subject to a tradeoff between different government goals. The choice of the system of foreign profit taxation has to account for the revenue implications and the tax effects on the competitiveness of domestic firms (and its market shares). Transfer price guidelines are chosen weighing off the loss in taxable income at the headquarter location and their effect on the variable cost of production. If the restriction on the number of available policy instruments is relaxed, e.g. if a direct production subsidy is allowed for, the picture changes substantially. It is straightforward to show that the tax exemption system would not be an optimal policy choice independent of the level of transfer prices. Of course, the question may arise whether a situation in which tax policy choices are the result of a trade-off between revenue and strategic trade goals is necessarily better than a situation in which direct subsidies are allowed for. Moreover, one might ask, if the world's trade organization banned direct subsidies, how should indirect subsidies (such as the tax exemption system) be evaluated. These questions are beyond the scope of the paper, though.

The remainder of the paper is organized as follows. In the following section, the model setup is described and the market equilibrium is derived. In section 3 , tax policy with given and endogenous transfer prices is analyzed. Section 4 discusses the results and section 5 concludes.

\section{The model}

Assume a world with three countries, labelled $a, b$ and $c$. There are two multinational firms (MNFs) with their headquarters in countries $a$ and $b$, respectively. Each of the two MNFs has an affiliate in country $c$ and produces a homogeneous good $x$ which is sold to consumers in country $c$. Demand in $c$ is denoted by $X$ and given by $X=A-p$ where $p$ is the price and $A$ is a constant parameter.

Consider firstly the production decisions of the multinational firm headquartered in country $i$. Production of one unit of $x_{i}$ requires one unit labor and one unit 
of capital. The unit cost of labor is given by $w$ in all locations ${ }^{10}$ and capital is rented at the world capital market at a constant rate of $r$. Production takes place at both locations within the firm, the headquarter in country $i$ and the affiliate in country $c$. I assume that a fraction $\theta$ of production is located at the headquarter and the complement, $1-\theta$, at the affiliate in country $c$. This can be interpreted as the headquarter producing some input good necessary for production in country $c$, or as the firm allocating different "tasks" across locations (like in Grossman \& Rossi-Hansberg, 2008). For accounting and tax purposes, the foreign affiliate has to "buy" the headquarter part of the production at a transfer price of $\delta_{i}$. Thus, the before-tax variable cost at the affiliate is given by $(1-\theta)(w+r)+\theta \delta_{i}$ and at the headquarter by $\theta(w+r)-\theta \delta_{i}$.

How are transfer prices determined? I assume that countries $a$ and $b$ - either cooperatively or uncoordinatedly - choose transfer price guidelines, denoted by $\bar{\delta}_{i}$. Firms may choose to deviate from the guideline by setting $\tilde{\delta}_{i}$. Deviating from the "official" transfer price fixed by the guideline is costly, though, since this deviation has to be concealed from detection. The concealment cost is assumed to equal $k_{i}\left(\tilde{\delta}_{i}-\bar{\delta}_{i}\right)$ with $k_{i}^{\prime}=\operatorname{sign}\left(\tilde{\delta}_{i}-\bar{\delta}_{i}\right)$ and $k_{i}^{\prime \prime}>0$.

After-tax profits are then given by

$$
\begin{aligned}
\pi_{i}= & {\left[\left(p\left(x_{i}, x_{j}\right)-w(1-\theta)-\theta \tilde{\delta}_{i}\right) x_{i}-F_{i}\right]\left(1-t_{i}^{e}\right) } \\
& +\left[\tilde{\delta}_{i}-w-k_{i}\left(\tilde{\delta}_{i}-\bar{\delta}_{i}\right)\right] \theta x_{i}\left(1-t_{i}\right)-r x_{i}
\end{aligned}
$$

where $t_{i}$ is the corporate tax in country $i, t_{i}^{e}=t_{c}+t_{i}^{r}\left(1-t_{c}\right)$ the effective tax rate on foreign profits, $t_{i}^{r}$ is the repatriation tax and $t_{c}$ the corporate tax in country $c$. Under the tax exemption system, $t_{i}^{r}$ equals zero, and under the tax credit system, $t_{i}^{r}$ is equal to $\frac{t_{i}-t_{c}}{1-t_{c}}$ yielding an effective tax rate on foreign profits of $t_{i}^{e}=t_{i}$. Note that, in the absence of taxes or under the tax credit system, with $t_{i}^{e}=t_{i}$, the transfer price does not affect firm profits. Throughout the paper, I assume that $t_{c}<t_{i}$.

The firm in $i$ maximizes its profits by strategically setting $x_{i}$ and $\tilde{\delta}_{i}$. Consider firstly the profit-maximizing choice of the transfer price $\tilde{\delta}_{i}$. The first order

\footnotetext{
${ }^{10}$ The equality of wages is not crucial for the model results, but simplifies notation.
} 
condition is given by

$$
t_{i}-t_{i}^{e}=-k_{i}^{\prime}\left(1-t_{i}\right)
$$

Under the tax credit system, $t_{i}^{e}=t_{i}$, the firm does not deviate from the transfer price guideline, $\tilde{\delta}_{i}=\bar{\delta}_{i}$. However, under the exemption system, $t_{i}>t_{i}^{e}=t_{c}, k_{i}^{\prime}$ has to be negative to satisfy the above condition which implies $\tilde{\delta}_{i}<\bar{\delta}_{i}$. The firm sets a lower transfer price than officially proposed in order to shift income from the high-tax headquarter location to the low-tax affiliate location.

Now consider the profit-maximizing quantity given by

$$
x_{i}=\frac{A-\kappa_{i}-\left(\kappa_{i}-\kappa_{j}\right)}{3}
$$

where $\kappa_{i}=w+\theta\left(\bar{\delta}_{i}-w\right)\left(\frac{t_{i}-t_{i}^{e}}{1-t_{i}^{e}}\right)-\frac{\Omega_{i}^{f}}{1-t_{i}^{e}}+\frac{r}{1-t_{i}^{e}}$ and $\kappa_{j}=w+\theta\left(\bar{\delta}_{j}-w\right)\left(\frac{t_{j}-t_{j}^{e}}{1-t_{j}^{e}}\right)-$ $\frac{\Omega_{j}^{f}}{1-t_{j}^{e}}+\frac{r}{1-t_{j}^{e}}$ are the variable costs of firms headquartered in $i$ and $j$, and $\Omega_{i}^{f}=$ $-\theta\left(\tilde{\delta}_{i}-\bar{\delta}_{i}\right)\left(t_{i}-t_{i}^{e}\right)-k_{i} \theta\left(1-t_{i}\right)>0$ and $\Omega_{j}^{f}=-\theta\left(\tilde{\delta}_{j}-\bar{\delta}_{j}\right)\left(t_{j}-t_{j}^{e}\right)-k_{j} \theta\left(1-t_{j}\right)$ are the firms' total gains from profit shifting (i.e., deviating from $\bar{\delta}$ ). Note that $\Omega_{i}^{f}$ and $\Omega_{j}^{f}$ do not depend on the level of $\bar{\delta}_{i}$ or $\bar{\delta}_{j}$, see also (2).

The equilibrium price is

$$
p=\frac{A+\kappa_{a}+\kappa_{b}}{3}
$$

It follows that the equilibrium quantity can be expressed as $x_{i}=p-\kappa_{i}$ and profits as $\pi_{i}=\left(\left(x_{i}\right)^{2}-F_{i}\right)\left(1-t_{i}^{e}\right)$.

It is useful to have a look at how policy choices affect the equilibrium quantities. A small increase in $t_{i}^{r}$ has the following impact on $x_{i}$ :

$$
\frac{\partial x_{i}}{\partial t_{i}^{r}}=-\frac{2}{3} \frac{\partial \kappa_{i}}{\partial t_{i}^{r}}=\frac{2}{3}\left[-\frac{r}{1-t_{i}}+\theta\left(\bar{\delta}_{i}-w\right)+\theta\left(\tilde{\delta}_{i}-\bar{\delta}_{i}-k_{i}\right)\right] \frac{\left(1-t_{i}\right)\left(1-t_{c}\right)}{\left(1-t_{i}^{e}\right)^{2}}
$$

An increase in $t_{i}^{r}$ has three effects. Firstly, it increases the capital cost since capital costs cannot be deducted from the corporate tax base (first term in square brackets). Secondly, it increases the tax deductions for the transfer price that the affiliate has to pay to the headquarter. This reduces ceteris paribus the variable cost and increases the equilibrium quantity. Thirdly, an increase in $t_{i}^{r}$ reduces the tax gap between the two locations and, thus, reduces the opportunities for profit 
shifting. The net effect on quantities is positive if the the official transfer price is large enough, i.e. if $\theta\left(\delta_{i}-w\right)>\frac{r}{1-t_{i}}-\theta\left(\tilde{\delta}_{i}-\bar{\delta}_{i}-k_{i}\right)$. Similarly, the impact of $t_{j}^{r}$ on $x_{i}$ is $\frac{\partial x_{i}}{\partial t_{j}^{r}}=\frac{1}{3} \frac{\partial \kappa_{j}}{\partial t_{j}^{r}}=\frac{2}{3}\left[-\frac{r}{1-t_{j}}+\theta\left(\bar{\delta}_{j}-w\right)+\theta\left(\tilde{\delta}_{j}-\bar{\delta}_{j}-k_{j}\right)\right] \frac{\left(1-t_{c}\right)\left(1-t_{j}\right)}{\left(1-t_{j}^{e}\right)^{2}}$.

The effect of a small increase in the transfer price $\delta_{i}$ is given by

$$
\frac{\partial x_{i}}{\partial \delta_{i}}-\frac{2}{3} \frac{\partial k_{i}}{\partial \bar{\delta}_{i}}=\frac{2}{3} k_{i}^{\prime} \theta\left(\frac{1-t_{i}}{1-t_{i}^{e}}\right)=-\frac{2}{3} \theta\left(\frac{t_{i}-t_{i}^{e}}{1-t_{i}^{e}}\right) \leq 0
$$

If the effective tax rates on income in both locations are equal, as under the credit system, the transfer price guideline (which then is the effective transfer price) is irrelevant for quantity and prices. However, if there is a difference in effective taxation between the headquarter and the affiliate in $c$, an increase in the transfer price leads to an increase in variable cost and, thus, decreases equilibrium quantity. The reason is that an increase in $\delta_{i}$ increases heavily taxed headquarter income and reduces lightly taxed affiliate income (without changing the sum of pre-tax income). Similarly, an increase in the transfer price of country $j$ increases the profit-maximizing quantity of the firm in $i, \frac{\partial x_{i}}{\partial \delta_{j}}=\frac{1}{3} \theta\left(\frac{t_{j}-t_{j}^{e}}{1-t_{j}^{e}}\right) \geq 0$, if it increases the variable cost of the firm in $j$.

\section{$3 \quad$ Welfare and optimal policy choices}

The literature on optimal foreign income taxation usually assumes that the government's objective is to maximize national income. Its focus is on the optimal tax on foreign income given the corporate tax rates at home and abroad. Thus, taxation in this literature is neither about redistribution nor about public good provision $^{11}$ but rather about correcting for allocative distortions due to corporate tax rate differences. Here, I adopt these assumptions. Accordingly, national welfare is assumed to be the sum of firm profits and tax revenue where the former is

\footnotetext{
${ }^{11}$ Note that if national income maximization is the government's objective the case for raising tax revenue is rather low compared to the cases in which funds are to be redistributed or used for public goods provision. Thus, the assumption makes exemption as an optimal policy outcome more likely.
} 
given in (1) and the latter by

$$
T_{i}=t_{i}^{r}\left(1-t_{c}\right)\left[\left(p-w(1-\theta)-\theta \tilde{\delta}_{i}\right) x_{i}-F_{i}\right]+t_{i} \theta\left(\tilde{\delta}_{i}-w-k_{i}\right) x_{i}
$$

Thus, welfare in country $i$ equals

$$
W_{i}=\left[\left(p-w+\frac{t_{c}}{1-t_{c}} \theta\left(\bar{\delta}_{i}-w\right)-\frac{\Omega_{i}^{g}}{1-t_{c}}-\frac{r}{1-t_{c}}\right) x_{i}-F_{i}\right]\left(1-t_{c}\right)
$$

where $\Omega_{i}^{g}=-\theta\left(\tilde{\delta}_{i}-\bar{\delta}_{i}\right) t_{c}+k_{i} \theta \geq 0$ denotes the social cost due to profit shifting. Taxes levied by country $i$ do not occur since they just redistribute funds from the private to the public sector which has no welfare implication, by assumption. The transfer price guideline $\bar{\delta}_{i}$ only plays a role if there is a non-zero corporate tax in the third market $c$ (recall that $\Omega_{i}^{g}$ is independent of the level of $\bar{\delta}_{i}$, see equation $(2))$.

Before I analyze optimal policy choices, it is worthwhile to consider how the benevolent government would like the firm to set its choices in comparison to how it actually sets it. The answer to this question is straightforward with regard to profit shifting. As $\Omega_{i}^{g}>0$, the government wants the firm to shift no profits at all. In terms of quantity, the picture is more complex. For purpose of illustration, assume that the government can force the firm to marginally increase its quantity. The effect on welfare is given by

$\frac{\partial W_{i}}{\partial x_{i}}=[\underbrace{-\frac{\partial x_{j}}{\partial x_{i}} x_{i}}_{\text {Brander\&Spencer(1985) }}+\underbrace{\theta\left(\bar{\delta}_{i}-w\right)\left(\frac{t_{i}-t_{i}^{r}}{1-t_{i}^{e}}\right)+\frac{t_{i}^{r} r}{1-t_{i}^{e}}}_{\text {Taxation effect }}-\underbrace{\left(\Omega_{i}^{f}+\Omega_{i}^{g}\right)}_{\text {Profit shifting effect }}]\left(1-t_{c}\right)$

By increasing $x_{i}$, the government acts as a Stackelberg leader and forces the firm in $j$ to reduce its quantity. This leads to an increase in $p$ as $\frac{\partial p}{\partial x_{j}}=-1$. This effect has been analyzed in a three country model by Brander \& Spencer (1985). In their framework, this effect provides the rationale for subsidizing production (via an export subsidy). The second effect is due to taxation. In the presence of taxes, firm choices have an effect on the government budget which is not accounted for by 
firms. Production is therefore inefficiently low. Therefore an increase of production increases welfare. The third effect is due to profit shifting opportunities. If profit shifting decreases variable cost, the firm ceteris paribus produces too much which ceteris paribus implies negative welfare effects of production increases. ${ }^{12}$

In the presence of a sufficient number of instruments, the government could suppress profit shifting and subsidize production in order to maximize national welfare. However, as outlined in the introduction, production subsidies may not be available due to international trade agreements. Moreover, the government may simply lack adequate instruments allowing for suppressing profit shifting at an acceptable cost. I assume that the only instruments available are the choice of the system of foreign profit taxation and eventually the choice of transfer price guidelines.

Depending on the extent of the profit shifting opportunities, i.e. the level of $\Omega_{i}^{f}$ and $\Omega_{i}^{g}$, production is either too high or too low. In the absence of profit shifting, production is inefficiently low. The question is therefore which of the two systems of taxation pushes the firm closer to the welfare-maximizing behavior. This is to be examined in the following. The analysis has two parts. In the first part, I assume that transfer prices are exogenously given, e.g. by some supranational transfer price guideline. In the second part, transfer prices can be set non-cooperatively and coordinatedly by countries $i$ and $j$.

\subsection{Tax policy with given transfer prices}

To start with, assume that transfer prices $\delta_{a}$ and $\delta_{b}$ are exogenously given, e.g. due to some earlier agreement or some supranational institution. Both governments in $a$ and $b$ simultaneously choose between the two standard systems of foreign taxation: exemption system and tax credit system. The governments' purpose is to maximize national welfare given by (8). Corporate tax rates $t_{a}$ and $t_{b}$ are assumed to be given, and the government in $c$ is passive. In the following, I will analyze country $i$ 's choice depending on given transfer prices and the choices of

\footnotetext{
${ }^{12}$ This effect has been analyzed in Grubert \& Slemrod (1998) and Slemrod (2003).
} 
country $j$ with $i, j=a, b$ and $i \neq j$. Its optimization problem is given by

$$
\max _{t_{i}^{e}} W_{i} \quad \text { with } t_{i}^{e} \in\left\{t_{i}, t_{c}\right\}
$$

With $\pi_{i}=\left(\left(x_{i}\right)^{2}-F_{i}\right)\left(1-t_{i}^{e}\right)$, welfare under the exemption system $(e x)$ can be expressed as

$$
W^{e x}=\pi_{i}^{e x}+t_{i} \theta\left(\tilde{\delta}_{i}^{e x}-w-k_{i}^{e x}\right) x_{i}^{e x}
$$

where $\pi_{i}^{e x}$ and $x_{i}^{e x}$ are profits and the profit-maximizing quantity, respectively, if country $i$ chooses the exemption system, see (3) with $t_{i}^{e}=t_{c}$. In contrast, welfare under the tax credit system is equal to

$$
W^{c r}=\pi_{i}^{c r}+t_{i}^{r}\left(1-t_{c}\right)\left[\left(p^{c r}-w(1-\theta)-\theta \bar{\delta}_{i}\right) x_{i}^{c r}-F_{i}\right]+t_{i} \theta\left(\bar{\delta}_{i}-w\right) x_{i}^{c r}
$$

where $\pi_{i}^{c r}$ and $x_{i}^{c r}$ are profits and the profit-maximizing quantity, respectively, if country $i$ chooses the tax credit system, see (3) with $t_{i}^{e}=t_{i}$.

Country $i$ chooses the exemption system if $W^{e x}>W^{c r}$. The welfare difference can be expressed as

$$
W_{i}^{e x}-W_{i}^{c r}=\left[\Psi-\frac{\kappa_{i}^{c r}-\kappa_{i}^{e x}}{3}\left(1-t_{c}\right)\right] \frac{2}{3}\left(\frac{\kappa_{i}^{c r}-\kappa_{i}^{e x}}{3}\right)-\Omega_{i}^{g, e x}
$$

where $\Psi$ is defined as $\Psi=t_{c} w(1-\theta)+t_{c} \theta \bar{\delta}_{i}+\frac{t_{i}-t_{c}}{1-t_{i}} r+\frac{x_{i}^{c r}}{2}>0$. Thus, the welfare difference is a quadratic function of the difference in variable cost, $\kappa_{i}^{c r}-\kappa_{i}^{e x}$. If the social cost of profit shifting, $\Omega_{i}^{g, e x}$, is sufficiently small, this function has two nulls, $N_{1}$ and $N_{2}$ (derived in the appendix), both larger than zero. However, if $\Omega_{i}^{g, e x}$ is high, the tax credit system is always preferred over the tax exemption system.

For $\kappa_{j}^{c r}>\kappa_{j}^{e x}, \Psi$ is larger if country $j$ chooses the exemption system, $t_{j}^{e}=t_{j}$. This implies that $W_{i}^{e x}-W_{i}^{c r}$ is larger of all positive cost differences $\kappa_{i}^{c r}-\kappa_{i}^{e x}$ under $t_{j}^{e}=t_{j}$ than under $t_{j}^{e}=t_{c}$.

The difference in marginal cost can be expressed as

$$
\kappa_{i}^{c r}-\kappa_{i}^{e x}=\frac{t_{i}-t_{c}}{1-t_{c}}\left[\frac{r}{1-t_{i}}-\theta\left(\bar{\delta}_{i}-w\right)\right]+\Omega_{i}^{f, e x}
$$


If $\bar{\delta}_{i}$ equals the variable cost at the headquarter, $w$, the variable cost under the tax credit system is always higher than the variable cost under exemption. Only for sufficiently large transfer price guidelines, the variable cost difference can become negative. Note that the firm's gain from profit shifting does not depend on the transfer price guideline $\bar{\delta}_{i}$.

Diagram 1 summarizes the results. Suppose that country $j$ applies the exemption system and that $\Omega_{i}^{g, e x}$ is sufficiently small. Then, if the variable cost under the credit system is lower or only little larger than the variable cost under the exemption system, country $i$ prefers the tax credit system (parameter range left of $N_{1}$ ). If the cost difference becomes larger, country $i$ switches to the exemption system (parameter range between $N_{1}$ and $N_{2}$ ). At $\kappa_{i}^{c r}-\kappa_{i}^{e x}=N_{2}$, it switches back to the tax credit system (parameter range right of $N_{2}$ ). If country $j$ applies the tax credit system, the nulls are at $\tilde{N}_{1}$ and $\tilde{N}_{2}$ which implies a larger parameter range at which the exemption system is the optimal tax policy choice.

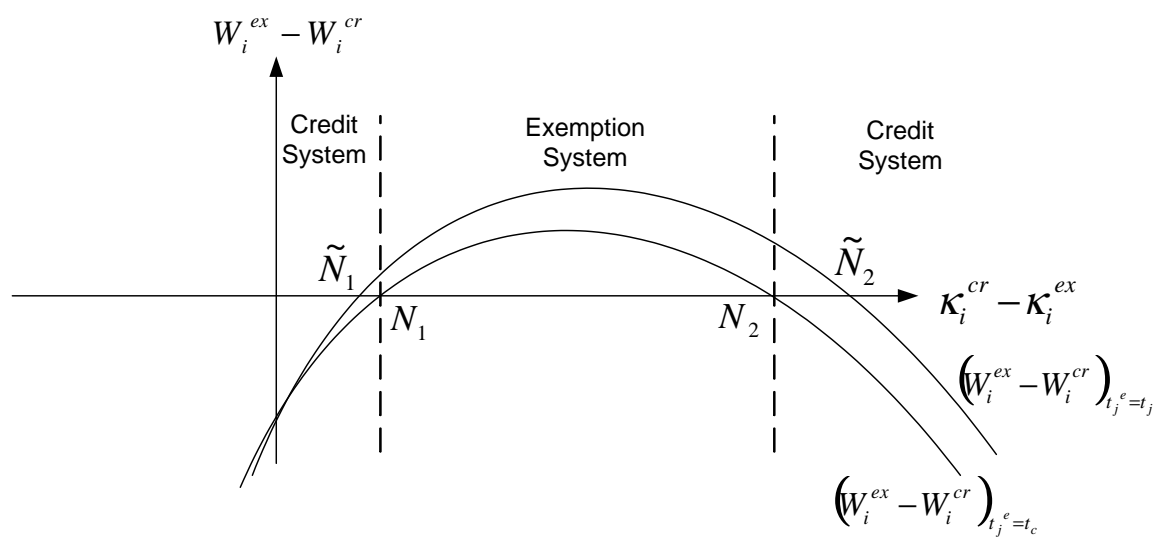

Diagram 1: Welfare difference as a function of variable cost difference.

I can thus state

Proposition 1 Assume that transfer price guidelines are exogenously given and equal in both countries, $\bar{\delta}_{a}=\bar{\delta}_{b}=\bar{\delta}$. Then, a Nash equilibrium exists with both countries choosing the tax credit system if the social loss due to profit shifting opportunities under the exemption system $\Omega_{i}^{g, e x}$ is large. If $\Omega_{i}^{g, e x}$ is sufficiently small,

i) a Nash equilibrium exists with both countries choosing the tax credit system if $\kappa_{i}^{c r}-\kappa_{i}^{e x}<\tilde{N}_{1}$ and $\kappa_{i}^{c r}-\kappa_{i}^{e x}>\tilde{N}_{2}$. 
ii) a Nash equilibrium exists with both countries choosing the tax exemption system if $N_{1}<\kappa_{i}^{c r}-\kappa_{i}^{e x}<N_{2}$.

iii) no equilibrium in pure strategies exists if $\tilde{N}_{1}<\kappa_{i}^{c r}-\kappa_{i}^{e x}<N_{1}$ and $N_{2}<$ $\kappa_{i}^{c r}-\kappa_{i}^{e x}<\tilde{N}_{2}$

One may summarize the above proposition as follows. In the absence of intrafirm trade, $\theta=0$, the exemption system is optimal. In the presence of intra-firm trade and if transfer price guidelines are close to actual costs at the headquarter location, see equation (14), the exemption system is an optimal policy choice and the equilibrium strategy as long as profit shifting opportunities are not too large. If transfer price guidelines are used to shift a fair amount of taxable income to the headquarter location (i.e. if transfer prices are sufficiently large), it is likely that the tax credit system is an optimal policy choice in both countries.

\subsection{Tax policy with endogenous transfer prices}

So far, I have assumed that transfer price guidelines are given. This may be a plausible assumption since countries agree on international transfer price guidelines which may have quasi-legal status in trade frameworks like the WTO. However, countries may have some discretion in setting the transfer price guidelines whether due to incomplete international arrangements or discretionary ranges allowed for in these arrangements. For this purpose, I assume that countries $a$ and $b$ can set the transfer price guidelines. Country $c$ is supposed to have no means to dispute the guidelines ${ }^{13}$ as long as there is a non-negative tax base in country $c$, i.e. as long as $\bar{\delta}_{i} \leq \bar{\delta}_{i}^{\max } \equiv \frac{1}{\theta}\left(p-w(1-\theta)-\frac{F_{i}}{x_{i}}\right)$. The optimization problem of country $i$ becomes

$$
\max _{t_{i}^{e}, \delta_{i}} W_{i} \quad \text { with } t_{i}^{e} \in\left\{t_{i}, t_{c}\right\} \text { and } \bar{\delta}_{i} \in\left[-\infty, \bar{\delta}_{i}^{\max }\right]
$$

Given $t_{i}^{e}$ and the policy choices of country $j$, the first-order condition for $\delta_{i}$ is

$\frac{\partial W_{i}}{\partial \bar{\delta}_{i}}=t_{c} \theta x_{i}+\left[\frac{1}{2} x_{i}+\theta\left(\bar{\delta}_{i}-w\right)\left(\frac{t_{i}-t_{i}^{r}}{1-t_{i}^{e}}\right)+\frac{t_{i}^{r} r}{1-t_{i}^{e}}-\frac{\Omega_{i}^{f}}{1-t_{i}^{e}}-\frac{\Omega_{i}^{g}}{1-t_{c}}\right]\left(1-t_{c}\right) \frac{\partial x_{i}}{\partial \bar{\delta}_{i}}=0$

${ }^{13}$ This assumption is further discussed in section 4. 
with $\frac{\partial x_{i}}{\partial \bar{\delta}_{i}}=-\frac{2}{3} \theta\left(\frac{t_{i}-t_{i}^{e}}{1-t_{i}^{e}}\right)$. Thus, the optimal transfer price guideline results from a trade-off between shifting taxable income to the domestic jurisdiction (and, thus, save foreign tax payments, see the first term) and distorting the cost of production (second term). This trade-off differs according to the system of foreign profit taxation.

Under the tax credit system, the quantity does not depend on the transfer price, $\frac{\partial x_{i}}{\partial \bar{\delta}_{i}}=0$. Thus, the government in country $i$ shifts all profits out of country $c$ by charging the highest possible transfer price, $\bar{\delta}_{i}^{\max }$, which implies profits of $\pi_{i}=\left[\left(p-w-\frac{r}{1-t_{i}}\right) x_{i}-F_{i}\right]\left(1-t_{i}\right)$ and tax revenue of $T_{i}=t_{i}\left((p-w) x_{i}-F_{i}\right)$ where $x_{i}$ and $p$ are given in (3) and (4), respectively.

Under the exemption system, country $i$ 's optimal transfer price depends on country $j$ 's choice of the tax system. The appendix shows that, if country $j$ chooses the tax credit system, the optimal $\bar{\delta}_{i}$ equals

$\left.\bar{\delta}_{i}\right|_{t_{j}^{e}=t_{j}}=w+\frac{3}{2} \frac{\left(\Omega_{i}^{f}+\Omega_{i}^{g}\right)}{\left(2 t_{c}+t_{i}\right) \theta}+\left(\frac{1-t_{c}}{t_{i}-t_{c}}\right) \frac{\left(4 t_{c}-t_{i}\right)\left(A-w+\frac{r}{1-t_{j}}+2 \frac{\Omega_{i}^{f}}{1-t_{c}}-2 \frac{r}{1-t_{c}}\right)}{4\left(2 t_{c}+t_{i}\right) \theta}$

If country $j$ chooses the tax credit system, the optimal transfer price guideline reads

$$
\begin{aligned}
\left.\bar{\delta}_{i}\right|_{t_{j}^{e}=t_{c}}= & w+\frac{2\left(12 t_{c}+3 t_{i}\right)}{\theta\left(5 t_{i}^{2}+24 t_{i} t_{c}+16 t_{c}^{2}\right)}\left(\Omega^{f}+\Omega^{g}\right) \\
& +\left(4 t_{c}-t_{i}\right)\left(\frac{1-t_{c}}{t_{i}-t_{c}}\right) \frac{\left(4 t_{c}+t_{i}\right)}{\theta\left(5 t_{i}^{2}+24 t_{i} t_{c}+16 t_{c}^{2}\right)}\left(A-w-\frac{r}{1-t_{c}}+\frac{\Omega^{f}}{1-t_{c}}\right)
\end{aligned}
$$

Thus, the choice of $\bar{\delta}_{i}$ depends on the tax systems choice in both countries and the tax rate in country $c, \bar{\delta}_{i}=\bar{\delta}_{i}\left(t_{i}^{e}, t_{j}^{e}, t_{c}\right)$, of which the latter is of crucial importance. It follows directly from the two above equations that $t_{c}>t_{i} / 4$ is a sufficient condition for the optimal transfer price guideline to exceed the variable cost at the headquarter: $\bar{\delta}_{i}>w$. The larger the firm's gain and the social loss due to profit shifting, the higher the optimal $\bar{\delta}_{i}$. To understand the relationship between $t_{c}$ and the optimal transfer price, recall that the transfer price has two main effects. Firstly, the transfer price can be used to manipulate the variable cost 
which is similar to a production subsidy. This effect becomes the more important the higher the tax gap $t_{i}-t_{c}$, i.e. the lower the foreign tax rate $t_{c}$. Secondly, the transfer price shifts income from the foreign tax base to the domestic tax base. From the domestic perspective, this is the more important the higher the foreign tax rate $t_{c}$. In other words, if the tax rate in country $c$ is low, transfer pricing is aggressive and competition oriented; if the tax rate in country $c$ is high, transfer pricing is tax revenue oriented.

Now, consider the choice between the exemption and the tax credit system. This choice is different from the choice analyzed in the preceding section: The firm either chooses exemption and the transfer price in (17) or (18), or the tax credit system and the maximum transfer price given by $\bar{\delta}_{i}^{\max }=\theta^{-1}\left(p-w(1-\theta)-\frac{F_{i}}{x_{i}}\right)$. Under exemption, national welfare is given by (11). In contrast, under the tax credit system, national welfare is given by $W_{i}^{c r}=(p-w-r) x_{i}-F_{i}$. Welfare does not depend on the tax rate in country $c$, since all taxable income is shifted out of country $c$. The country has no opportunity to use transfer prices to subsidize production, however it can shift all income out of country $c$ without deteriorating the terms of trade of its firm.

Proposition 2 Assume that transfer prices and tax regimes are simultaneously and uncoordinatedly chosen by both countries $a$ and $b$. Then,

i) if $t_{c}$ approaches zero, both countries choose the exemption system;

ii) if the foreign tax rate approaches $t_{i}$, both countries prefer the tax credit system.

Proof. Assume $t_{c}=0$. Then, under the tax credit system, the transfer price has no impact on welfare. Under an exemption system, country $i$ can replicate the welfare level of the tax credit system by setting an adequate transfer price (at $N_{1}$ or $\tilde{N}_{1}$, respectively, in diagram 1). However, changing the transfer price may increase welfare even higher. Thus, the welfare under the exemption system can be increased by setting lower transfer prices (and, thus, increase $\kappa_{i}^{c r}-\kappa_{i}^{e x}$ ). If $t_{c}$ increases, the first term in (17) and (18) decrease whereas the second terms increase. If $t_{c}$ approaches $t_{i}, \delta_{i}$ will at some point reach its maximum level given by $\delta_{i}^{\max }$ (due to the term $t_{i}-t_{c}$ in the denominator). As shown in the preceding section, a sufficient condition for a country to prefer the credit system is $\kappa_{i}^{c r}-\kappa_{i}^{e x}<0$ 
which implies $\bar{\delta}_{i}>w+\frac{r}{\theta\left(1-t_{i}\right)}-\left(\tilde{\delta}_{i}-\bar{\delta}_{i}\right)\left(1-t_{c}\right)-\left(\frac{1-t_{c}}{t_{i}-t_{c}}\right) k_{i}\left(1-t_{i}\right)$. Thus, it suffices to show that $\delta_{i}^{\max }>w+\frac{r}{\theta\left(1-t_{i}\right)}-\left(\tilde{\delta}_{i}-\bar{\delta}_{i}\right)\left(1-t_{c}\right)-\left(\frac{1-t_{c}}{t_{i}-t_{c}}\right) k_{i}\left(1-t_{i}\right)$ in order to prove that, for high levels of $t_{c}$, the preferred tax system is the tax credit system. It is straightforward to show that it actually is higher if $\left(\frac{p-w-\frac{F_{i}}{x_{i}}-\frac{r}{\left(1-t_{i}\right)}}{\theta}\right)>$ $\left[-\left(\tilde{\delta}_{i}-\bar{\delta}_{i}\right)-k_{i}\left(\frac{1-t_{i}}{t_{i}-t_{c}}\right)\right]\left(1-t_{c}\right)$ which is necessarily true for high levels of $t_{c}$ approaching $t_{i}$.

Thus, countries choose the credit system if income shifting to the domestic tax base is more important (i.e. if $t_{c}$ is large) and the exemption system if subsidization is more effective (i.e. if $t_{c}$ is low).

\subsection{Extension: Tax rate choice of country $c$}

So far, I have assumed that country $c$ is passive and does not respond to the policy choices of countries $a$ and $b$. However, the model results have shown that optimal policy choices with endogenous transfer prices crucially depend on the tax policy choice of $c$, the tax rate $t_{c}$. For reasons discussed above, I have assumed that countries $a$ and $b$ consider their corporate tax rates as given, and it is natural to apply the same assumption to country $c$. In fact, tax competition over corporate tax rates has been extensively analyzed in the literature, in symmetric settings (countries $a$ and $b$ ) and asymmetric settings (countries $c$ and $a / b$ ). Replicating this kind of analysis is not likely to yield new insights. It is, however, tempting to ask whether country $c$ has an incentive to trigger certain policy responses by country $a$ and $b$ by setting its tax rate before $a$ and $b$ choose their system of foreign profit taxation and the transfer price guidelines.

Therefore assume that country $c$ acts as a Stackelberg leader and determines its tax rate $t_{c}$ anticipating the other countries' policy choices on $t_{a}^{e}, t_{b}^{e}, \bar{\delta}_{a}, \bar{\delta}_{b}$. As indicated above, both countries $a$ and $b$ choose their system of foreign profit taxation according to a trade-off between production subsidization and income shifting out of country $c$. Whereas production subsidies benefit the economy in $c$ because consumer surplus increases, income shifting reduces the country's tax revenue. In other words, subsidizing production by country $i$ harms country $j$ and benefits country $c$, whereas income shifting under the tax credit system does 
not affect country $j$ but harms country $c$. Therefore, country $c$ clearly prefers the other two countries to implement the exemption system.

Proposition 3 If country $c$ is allowed to adjust its tax rate $t_{c}$, the resulting equilibrium implies both countries a and b choosing the exemption system.

Proof. If $t_{c}$ is large, both countries $a$ and $b$ choose the tax credit system and country $c$ has zero tax revenue and consumer prices of $p\left(t_{i}^{e}=t_{i}\right)$. If $t_{c}$ is low, countries $a$ and $b$ choose the exemption system and country $c$ has zero or positive tax revenue and consumer prices of $p\left(t_{i}^{e}=t_{c}\right)$. Since tax revenue cannot become negative and because $p\left(t_{i}^{e}=t_{c}\right)<p\left(t_{i}^{e}=t_{i}\right)$, it follows that country $c$ always chooses a tax rate which ensures a tax exemption equilibrium.

This result stands in contrast to the standard literature where the low-tax country may profit from tax credit system employed by the high-tax country. The reason is that the low-tax country may then increase its tax rate without distorting the incentives for the foreign owned capital.

\section{Discussion}

As every model, the above presented model is based on a number of simplifying assumptions. In the following, I will discuss three of these simplifications and their implications for the model results.

Firstly, I assumed for most of the model analysis that country $c$ remains passive, especially in terms of transfer pricing policies. In the real world, transfer prices are negotiated between the two parties which are directly concerned: the residence country and the host country. Other residence countries (like country $j$ in the model) are affected by the outcome of these negotiations but do not participate. Assuming that the host country is passive is equivalent to assuming that it has no negotiation power. This greatly simplifies the analysis but, as I will argue here, does not substantially restrict the results in their generality. On the one hand, in many cases the residence country has incentives to allow for profit shifting to the low tax host country in order to subsidize production. On the other hand, if the host country has negotiation power this would simply imply that the highest 
possible transfer price is reduced. This does not affect the results derived in section 3.2 , though.

Secondly, I assumed that the firm's headquarter and affiliate act as one player. There are not principle-agent or management control problems involved. As pointed out by Elitzur \& Mintz (1996) and Koethenbuerger (2010), transfer pricing may be used by the headquarter to incentivize managers at the affiliate location. For instance, in order to reduce the risk of empire-building behavior, transfer prices may be chosen artificially high. In the cases described above, such a transfer pricing policy gets in conflict with the firm's tax saving purposes. Again, if countries anticipate this transfer pricing behavior, they may choose official transfer prices accordingly and end up at the transfer price levels as in the current version of the model. However, additional complexities arise as the affiliate part of the firm is not committed to profit-maximization.

Thirdly, the model considers perfect tax credit systems and perfect exemption systems. It has often been argued that real world versions of both tax systems actually are somewhere between the polar cases considered here. Deferral of profit repatriations undermine the tax credit system, and legislation for controlled foreign companies (CFC rules) introduce elements of residence taxation into real world exemption systems. Insofar, the model is not intended to reflect all complexities of existing tax systems, but rather focus on a major trade-off between revenue policy and trade policy which so far has mostly been neglected.

\section{Conclusion}

This paper started from the observation that explicit subsidies and tariffs are decreasing in importance due to international trade agreements. However, the tax system offers subtle means to manipulate the terms of trade for multinational firms, especially if intra-firm trade occurs. I built a model in the tradition of Brander \& Spencer (1985) where two firms from different countries compete on a third market. In contrast to the Brander \& Spencer (1985) framework, the firms have production facilities in the third market, but nevertheless import a fraction of their production from the headquarters. This gives rise to intra-firm trade which requires transfer price guidelines for tax reasons. The governments 
of the countries hosting the headquarters have two instruments at their disposal, the choice of the system of foreign profit taxation and transfer price guidelines. The paper demonstrates how the two instruments interdepend and what are the optimal choices under competition.

Firstly, it turns out that, in the absence of intra-firm trade both countries choose the exemption system. This is not a novel result, as it has often been mentioned in the literature and recent policy documents. As each residence country would like to subsidize production of its multinational firm, it certainly will not impose an extra cost on production via the repatriation tax.

Secondly, the picture changes in the presence of intra-firm trade, if transfer prices are exogenously given (e.g. by some international agreement) and ensure that there is positive taxable income in both locations, the headquarter and the affiliate. If intra-firm trade becomes more important, the residence country may have an incentive to switch to the tax credit system. The reason is that a transfer price that shifts taxable profits to the high-tax country increases the variable cost of the firm if there is a difference in effective taxation between the two locations. The tax credit system closes this tax gap and, thus, ceteris paribus reduces the variable cost.

Thirdly, if transfer prices are autonomously chosen by the residence countries a trade-off occurs between extracting income from the source country or implicitly subsidizing production. If the welfare objective is assumed to be national income, there is only an incentive to shift income out of the source country if it applies a positive corporate tax rate. It turns out that optimal transfer prices are below the variable headquarter cost of production if the source country's corporate tax rate is low and above if it approaches the corporate tax rate level of the residence country. The paper shows that, as a consequence, the residence countries prefer the exemption system for low corporate tax levels in the third country and the tax credit system otherwise.

Fourthly and finally, if the source country is allowed to adjust its tax rate, it can be shown that it will choose a corporate tax rate which is sufficiently low to ensure that both residence countries choose the exemption system.

What follows for tax policy? The most important message from the above analysis is probably that the competitive effects of the tax credit and the exemption 
system crucially depend on quantity and price of intra-firm trade. Moreover, as also pointed out by Becker \& Loomer (2009), transfer pricing may have a substantial effect on competition and should be treated accordingly by supranational competition institutions.

\section{References}

[1] Becker, J. (2009). Taxation of Foreign Profits with Heterogeneous Multinational Firms, CESifo Working Paper Series No. 2899.

[2] Becker, J. and Fuest, C. (2009). Transfer Pricing Policy and the Intensity of Tax Rate Competition, Oxford University Centre for Business Taxation Working Paper Series No. 09/30.

[3] Becker, J. and Fuest, C. (2010). Taxing Foreign Profits with International Mergers and Acquisitions, International Economic Review 51(1): 171-186.

[4] Becker, J. and Loomer, G. T. (2009). Tax havens and production subsidies as substitutes - Economic and legal implications, mimeo.

[5] Bernard, A. B.; Jensen, J. B. and Schott, P. K. (2006), Transfer Pricing by US-Based Multinational Firms, NBER Working Paper 12493.

[6] Bernard, J.-T. and Weiner, R. J. (1990). Multinational Corporations, Transfer Prices and Taxes: Evidence from the US Petroleum Industry, in: Assaf Razin and Joel Slemrod, eds., Taxation in the Global Economy, Chicago: University of Chicago Press, 123-154.

[7] Bond, E. W. and Samuelson, L. (1989). Strategic Behavior and the Rules for International Taxation of Capital, Economic Journal 99(398): 1099-1111.

[8] Brander, J. A. and Spencer, B. J. (1985). Export subsidies and international market share rivalry, Journal of International Economics 18: 83-100.

[9] Clausing, K. A. (2003). Tax-Motivated Transfer Pricing and US Intrafirm Trade, Journal of Public Economics 87: 2207-2223. 
[10] Coalition Agreement between CDU, CSU and FDP (2009). Growth. Education. Unity. http://www.cdu.de/doc/pdfc/091215-koalitionsvertrag-20092013-englisch.pdf (downloaded on 19/5/2010).

[11] Desai, M. A. and Hines, J. R. (2003). Evaluating International Tax Reform, National Tax Journal 56(3): 487-502.

[12] Desai, M. A. and Hines, J. R. (2004). Old Rules and New Realities: Corporate Tax Policy in a Global Setting, National Tax Journal 57(4): 937-60.

[13] Desai, M. A. (2009). Securing Jobs or the New Protectionism?: Taxing the Overseas Activities of Multinational Firms, Harvard Business School Finance Working Paper No. 09-107.

[14] Devereux, M. P. (2007). The Impact of Taxation on the Location of Capital, Firms and Profit: A Survey of Empirical Evidence, Oxford University Centre for Business Taxation Working Paper Series No. 07/2.

[15] Devereux, M. P. (2008). Taxation of Outbound Direct Investment: Economic Principles and Tax Policy Considerations, Oxford Review of Economic Policy 24(4): 698-719.

[16] Devereux, M. P. and Keuschnigg, C. (2009). The distorting arm's length principle, Oxford University Centre for Business Taxation Working Paper Series No. 09/10.

[17] Elitzur, R. and Mintz, J. (1996). Transfer pricing rules and corporate tax competition, Journal of Public Economics 60(3): 401-422.

[18] Grossman, G. M. and Rossi-Hansberg, E. (2008). Trading Tasks: A Simple Theory of Offshoring, American Economic Review 98(5): 1978-1997.

[19] Grubert, H. and Slemrod J. (1998). The Effect of Taxes on Investment and Income Shifting to Puerto Rico, Review of Economics \& Statistics 80(3): 365373.

[20] Hines, J. R. (2009). Reconsidering the Taxation of Foreign Income, Tax Law Review 62(2): 269-98. 
[21] HM Treasury and HM Revenue and Customs (2007). Taxation of Companies' Foreign Profits: Discussion Document.

[22] Holmstrom, B. and Tirole, J. (1991). Transfer Pricing and Organizational Form, Journal of Law, Economics \& Organization 7(2): 201-228.

[23] Huizinga, H. and Laeven, L. (2008). International Profit Shifting Within European Multinationals, Journal of Public Economics, 92(5/6): 1164-1182.

[24] Koethenbuerger, M. (2010). Profit Shifting and Agency Costs in Multinational Enterprises, mimeo.

[25] Mintz, J. and Tulkens, H. (1996). Optimality Properties of Alternative Systems of Taxation of Foreign Capital Income, Journal of Public Economics 60(3): 373-399.

[26] Musgrave, P. B. (1969). United States Taxation of Foreign Investment Income: Issues and Arguments, Cambridge (MA), International Tax Program, Harvard Law School.

[27] Overesch, M. (2006). Transfer Pricing of Intrafirm Sales as a Profit Shifting Channel - Evidence from German Firm Data, ZEW Discussion Paper 6084.

[28] Richman, P. B. (1963). Taxation of Foreign Investment Income - An Economic Analysis, The Johns Hopkins Press, Baltimore.

[29] Slemrod, J. (2001). A General Model of the Behavioral Response to Taxation, International Tax and Public Finance 8(2): 119-28.

[30] United States Department of the Treasury, Office of Tax Policy (2007). Approaches to Improve the Competitiveness of the US Business Tax System for the 21st Century. 


\section{Appendix}

\section{Appendix 1: Welfare difference}

This appendix derives the two nulls of the welfare difference function in equation (13).

The welfare level is given by

$$
W_{i}^{e x}-W_{i}^{c r}=\left[\Psi-\frac{\kappa_{i}^{c r}-\kappa_{i}^{e x}}{3}\left(1-t_{c}\right)\right] \frac{2}{3}\left(\frac{\kappa_{i}^{c r}-\kappa_{i}^{e x}}{3}\right)-\Omega_{i}^{g, e x}
$$

Thus, $W_{i}^{e x}-W_{i}^{c r}$ is a quadratic function of the cost difference $\kappa_{i}^{c r}-\kappa_{i}^{e x}$ :

$$
W_{i}^{e x}-W_{i}^{c r}=-\left(1-t_{c}\right) \frac{2}{27}\left[\left(\kappa_{i}^{c r}-\kappa_{i}^{e x}\right)^{2}-\frac{3 Y}{\left(1-t_{c}\right)}\left(\kappa_{i}^{c r}-\kappa_{i}^{e x}\right)+\frac{27}{2\left(1-t_{c}\right)} \Omega_{i}^{g, e x}\right]
$$

which has two nulls at

$$
\kappa_{i}^{c r}-\kappa_{i}^{e x}=\frac{3 Y}{2\left(1-t_{c}\right)} \pm \sqrt{\frac{1}{4}\left(\frac{3 Y}{\left(1-t_{c}\right)}\right)^{2}-\frac{27}{2\left(1-t_{c}\right)} \Omega_{i}^{g, e x}}
$$

If $\Omega_{i}^{g, e x}$ is sufficiently small, the two nulls $N_{1}$ and $N_{2}$ have positive signs:

$$
\begin{aligned}
& N_{1}=\frac{3 Y}{2\left(1-t_{c}\right)}-\sqrt{\frac{\left(\frac{3 Y}{\left(1-t_{c}\right)}\right)^{2}}{4}-\frac{27}{2\left(1-t_{c}\right)} \Omega_{i}^{g, e x}} \geq 0 \\
& N_{2}=\frac{3 Y}{2\left(1-t_{c}\right)}+\sqrt{\frac{\left(\frac{3 Y}{\left(1-t_{c}\right)}\right)^{2}}{4}-\frac{27}{2\left(1-t_{c}\right)} \Omega_{i}^{g, e x}}>0
\end{aligned}
$$

\section{Appendix 2: Optimal transfer pricing guidelines}

This appendix derives the expressions in equations (17) and (18). 
The first order condition is given by

$$
\begin{aligned}
\frac{\partial W_{i}}{\partial \bar{\delta}_{i}}= & \left(\frac{1}{2} x_{i}+\theta\left(\bar{\delta}_{i}-w\right)\left(\frac{t_{i}-t_{i}^{r}}{1-t_{i}^{e}}\right)+\frac{t_{i}^{r} r}{1-t_{i}^{e}}-\frac{\Omega_{i}^{f}}{1-t_{i}^{e}}-\frac{\Omega_{i}^{g}}{1-t_{c}}\right)\left(1-t_{c}\right) \frac{\partial x_{i}}{\partial \bar{\delta}_{i}} \\
& +t_{c} \theta x_{i}
\end{aligned}
$$

Using

$$
x_{i}=\frac{A-w-\frac{\Omega_{j}^{f}}{1-t_{j}^{e}}+\theta\left(\bar{\delta}_{j}-w\right)\left(\frac{t_{j}-t_{j}^{e}}{1-t_{j}^{e}}\right)+\frac{r}{1-t_{j}^{e}}-2 \theta\left(\bar{\delta}_{i}-w\right)\left(\frac{t_{i}-t_{i}^{e}}{1-t_{i}^{e}}\right)+2 \frac{\Omega_{i}^{f}}{1-t_{i}^{e}}-2 \frac{r}{1-t_{i}^{e}}}{3}
$$

and solving for $\bar{\delta}_{i}$ yields

$$
\begin{aligned}
\bar{\delta}_{i}= & w+\frac{3}{2} \frac{\left(\Omega_{i}^{f}+\Omega_{i}^{g}\right)}{\left(2 t_{c}+t_{i}\right) \theta} \\
& +\left(\frac{1-t_{c}}{t_{i}-t_{c}}\right) \frac{\left(4 t_{c}-t_{i}\right)\left(A-w-\frac{\Omega_{j}^{f}}{1-t_{j}^{e}}+\theta\left(\bar{\delta}_{j}-w\right)\left(\frac{t_{j}-t_{j}^{e}}{1-t_{j}^{e}}\right)+\frac{r}{1-t_{j}^{e}}+2 \frac{\Omega_{i}^{f}}{1-t_{c}}-2 \frac{r}{1-t_{c}}\right)}{4\left(2 t_{c}+t_{i}\right) \theta}
\end{aligned}
$$

where I used $t_{i}^{e}=t_{c}$.

If $j$ chooses credits, the above equation reads

$$
\bar{\delta}_{i}=w+\frac{3}{2} \frac{\left(\Omega_{i}^{f}+\Omega_{i}^{g}\right)}{\left(2 t_{c}+t_{i}\right) \theta}+\left(\frac{1-t_{c}}{t_{i}-t_{c}}\right) \frac{\left(4 t_{c}-t_{i}\right)\left(A-w+\frac{r}{1-t_{j}}+2 \frac{\Omega_{i}^{f}}{1-t_{c}}-2 \frac{r}{1-t_{c}}\right)}{4\left(2 t_{c}+t_{i}\right) \theta}
$$

If $j$ chooses exemption, the above equation reads

$$
\begin{aligned}
\bar{\delta}_{i}= & w+\frac{3}{2} \frac{\left(\Omega_{i}^{f}+\Omega_{i}^{g}\right)}{\left(2 t_{c}+t_{i}\right) \theta} \\
& +\left(\frac{1-t_{c}}{t_{i}-t_{c}}\right) \frac{\left(4 t_{c}-t_{i}\right)\left(A-w-\frac{r}{1-t_{c}}-\frac{\Omega_{j}^{f}}{1-t_{c}}+\theta\left(\bar{\delta}_{j}-w\right)\left(\frac{t_{j}-t_{c}}{1-t_{c}}\right)+2 \frac{\Omega_{i}^{f}}{1-t_{c}}\right)}{4\left(2 t_{c}+t_{i}\right) \theta}
\end{aligned}
$$


Accordingly, $j$ chooses

$$
\begin{aligned}
\bar{\delta}_{j}= & w+\frac{3}{2} \frac{\left(\Omega_{j}^{f}+\Omega_{j}^{g}\right)}{\left(2 t_{c}+t_{j}\right) \theta} \\
& +\left(\frac{1-t_{c}}{t_{j}-t_{c}}\right) \frac{\left(4 t_{c}-t_{j}\right)\left(A-w-\frac{r}{1-t_{c}}-\frac{\Omega_{i}^{f}}{1-t_{c}}+\theta\left(\bar{\delta}_{i}-w\right)\left(\frac{t_{i}-t_{c}}{1-t_{c}}\right)+2 \frac{\Omega_{j}^{f}}{1-t_{c}}\right)}{4\left(2 t_{c}+t_{j}\right) \theta}
\end{aligned}
$$

Plugging the above expression for $\bar{\delta}_{j}$ in the expression for $\bar{\delta}_{i}$ yields

$$
\begin{aligned}
\left(\bar{\delta}_{i}-w\right) \theta= & \frac{6\left[4\left(2 t_{c}+t_{j}\right)\left(\Omega_{i}^{f}+\Omega_{i}^{g}\right)+\left(4 t_{c}-t_{i}\right)\left(\Omega_{j}^{f}+\Omega_{j}^{g}\right)\left(\frac{t_{j}-t_{c}}{t_{i}-t_{c}}\right)\right]}{16\left(2 t_{c}+t_{i}\right)\left(2 t_{c}+t_{j}\right)-\left(4 t_{c}-t_{i}\right)\left(4 t_{c}-t_{j}\right)} \\
& +\left(\frac{1-t_{c}}{t_{i}-t_{c}}\right) \frac{4\left(4 t_{c}-t_{i}\right)\left(2 t_{c}+t_{j}\right)\left(A-w-\frac{r}{1-t_{c}}-\frac{\Omega_{j}^{f}}{1-t_{c}}+2 \frac{\Omega_{i}^{f}}{1-t_{c}}\right)}{16\left(2 t_{c}+t_{i}\right)\left(2 t_{c}+t_{j}\right)-\left(4 t_{c}-t_{i}\right)\left(4 t_{c}-t_{j}\right)} \\
& +\frac{1-t_{c}}{t_{i}-t_{c}} \frac{\left(4 t_{c}-t_{i}\right)\left(4 t_{c}-t_{j}\right)\left(A-w-\frac{r}{1-t_{c}}-\frac{\Omega_{i}^{f}}{1-t_{c}}+2 \frac{\Omega_{j}^{f}}{1-t_{c}}\right)}{16\left(2 t_{c}+t_{i}\right)\left(2 t_{c}+t_{j}\right)-\left(4 t_{c}-t_{i}\right)\left(4 t_{c}-t_{j}\right)}
\end{aligned}
$$

which, under symmetry, reads

$$
\begin{aligned}
\bar{\delta}_{i}= & w+\frac{2\left(12 t_{c}+3 t_{i}\right)}{\theta\left(5 t_{i}^{2}+24 t_{i} t_{c}+16 t_{c}^{2}\right)}\left(\Omega^{f}+\Omega^{g}\right) \\
& +\left(4 t_{c}-t_{i}\right)\left(\frac{1-t_{c}}{t_{i}-t_{c}}\right) \frac{\left(4 t_{c}+t_{i}\right)}{\theta\left(5 t_{i}^{2}+24 t_{i} t_{c}+16 t_{c}^{2}\right)}\left(A-w-\frac{r}{1-t_{c}}+\frac{\Omega^{f}}{1-t_{c}}\right)
\end{aligned}
$$




\section{CESifo Working Paper Series}

for full list see www.cesifo-group.org/wp

(address: Poschingerstr. 5, 81679 Munich, Germany, office@cesifo.de)

3001 Bertrand Candelon and Franz C. Palm, Banking and Debt Crises in Europe: The Dangerous Liaisons?, March 2010

3002 Joan Costa-i-Font and Marin Gemmill-Toyama, Does Cost Sharing really Reduce Inappropriate Prescriptions?, March 2010

3003 Scott Barrett, Climate Treaties and Backstop Technologies, March 2010

3004 Hans Jarle Kind, Tore Nilssen and Lars Sørgard, Price Coordination in Two-Sided Markets: Competition in the TV Industry, March 2010

3005 Jay Pil Choi and Heiko Gerlach, Global Cartels, Leniency Programs and International Antitrust Cooperation, March 2010

3006 Aneta Hryckiewicz and Oskar Kowalewski, Why do Foreign Banks Withdraw from other Countries? A Panel Data Analysis, March 2010

3007 Eric A. Hanushek and Ludger Woessmann, Sample Selectivity and the Validity of International Student Achievement Tests in Economic Research, March 2010

3008 Dennis Novy, International Trade and Monopolistic Competition without CES: Estimating Translog Gravity, April 2010

3009 Yin-Wong Cheung, Guonan Ma and Robert N. McCauley, Renminbising China's Foreign Assets, April 2010

3010 Michel Beine and Sara Salomone, Migration and Networks: Does Education Matter more than Gender?, April 2010

3011 Friedrich Schneider, Tilman Brück and Daniel Meierrieks, The Economics of Terrorism and Counter-Terrorism: A Survey (Part I), April 2010

3012 Friedrich Schneider, Tilman Brück and Daniel Meierrieks, The Economics of Terrorism and Counter-Terrorism: A Survey (Part II), April 2010

3013 Frederick van der Ploeg and Steven Poelhekke, The Pungent Smell of "Red Herrings": Subsoil Assets, Rents, Volatility and the Resource Curse, April 2010

3014 Vjollca Sadiraj, Jan Tuinstra and Frans van Winden, Identification of Voters with Interest Groups Improves the Electoral Chances of the Challenger, April 2010

3015 Guglielmo Maria Caporale, Davide Ciferri and Alessandro Girardi, Time-Varying Spot and Futures Oil Price Dynamics, April 2010 
3016 Scott Alan Carson, Racial Differences in Body-Mass Indices for Men Imprisoned in $19^{\text {th }}$ Century US Prisons: A Multinomial Approach, April 2010

3017 Alessandro Fedele, Paolo M. Panteghini and Sergio Vergalli, Optimal Investment and Financial Strategies under Tax Rate Uncertainty, April 2010

3018 Laurence Jacquet, Take it or Leave it: Take-up, Optimal Transfer Programs, and Monitoring, April 2010

3019 Wilhelm Kohler and Jens Wrona, Offshoring Tasks, yet Creating Jobs?, April 2010

3020 Paul De Grauwe, Top-Down versus Bottom-Up Macroeconomics, April 2010

3021 Karl Ove Aarbu, Demand Patterns for Treatment Insurance in Norway, April 2010

3022 Toke S. Aidt and Jayasri Dutta, Fiscal Federalism and Electoral Accountability, April 2010

3023 Bahram Pesaran and M. Hashem Pesaran, Conditional Volatility and Correlations of Weekly Returns and the VaR Analysis of 2008 Stock Market Crash, April 2010

3024 Stefan Buehler and Dennis L. Gärtner, Making Sense of Non-Binding Retail-Price Recommendations, April 2010

3025 Leonid V. Azarnert, Immigration, Fertility, and Human Capital: A Model of Economic Decline of the West, April 2010

3026 Christian Bayer and Klaus Wälde, Matching and Saving in Continuous Time: Theory and 3026-A Matching and Saving in Continuous Time: Proofs, April 2010

3027 Coen N. Teulings and Nick Zubanov, Is Economic Recovery a Myth? Robust Estimation of Impulse Responses, April 2010

3028 Clara Graziano and Annalisa Luporini, Optimal Delegation when the Large Shareholder has Multiple Tasks, April 2010

3029 Erik Snowberg and Justin Wolfers, Explaining the Favorite-Longshot Bias: Is it RiskLove or Misperceptions?, April 2010

3030 Doina Radulescu, The Effects of a Bonus Tax on Manager Compensation and Welfare, April 2010

3031 Helmut Lütkepohl, Forecasting Nonlinear Aggregates and Aggregates with Timevarying Weights, April 2010

3032 Silvia Rocha-Akis and Ronnie Schöb, Welfare Policy in the Presence of Unionised Labour and Internationally Mobile Firms, April 2010

3033 Steven Brakman, Robert Inklaar and Charles van Marrewijk, Structural Change in OECD Comparative Advantage, April 2010 
3034 Dirk Schindler and Guttorm Schjelderup, Multinationals, Minority Ownership and TaxEfficient Financing Structures, April 2010

3035 Christian Lessmann and Gunther Markwardt, Decentralization and Foreign Aid Effectiveness: Do Aid Modality and Federal Design Matter in Poverty Alleviation?, April 2010

3036 Eva Deuchert and Conny Wunsch, Evaluating Nationwide Health Interventions when Standard Before-After Doesn't Work: Malawi's ITN Distribution Program, April 2010

3037 Eric A. Hanushek and Ludger Woessmann, The Economics of International Differences in Educational Achievement, April 2010

3038 Frederick van der Ploeg, Aggressive Oil Extraction and Precautionary Saving: Coping with Volatility, April 2010

3039 Ainura Uzagalieva, Evžen Kočenda and Antonio Menezes, Technological Imitation and Innovation in New European Union Markets, April 2010

3040 Nicolas Sauter, Jan Walliser and Joachim Winter, Tax Incentives, Bequest Motives, and the Demand for Life Insurance: Evidence from two Natural Experiments in Germany, April 2010

3041 Matthias Wrede, Multinational Capital Structure and Tax Competition, April 2010

3042 Burkhard Heer and Alfred Maussner, A Note on the Computation of the Equity Premium and the Market Value of Firm Equity, April 2010

3043 Kristiina Huttunen, Jukka Pirttilä and Roope Uusitalo, The Employment Effects of Low-Wage Subsidies, May 2010

3044 Matthias Kalkuhl and Ottmar Edenhofer, Prices vs. Quantities and the Intertemporal Dynamics of the Climate Rent, May 2010

3045 Bruno S. Frey and Lasse Steiner, Pay as you Go: A New Proposal for Museum Pricing, May 2010

3046 Henning Bohn and Charles Stuart, Population under a Cap on Greenhouse Gas Emissions, May 2010

3047 Balázs Égert and Rafal Kierzenkowski, Exports and Property Prices in France: Are they Connected?, May 2010

3048 Thomas Eichner and Thorsten Upmann, Tax-Competition with Involuntary Unemployment, May 2010

3049 Taiji Furusawa, Kazumi Hori and Ian Wooton, A Race beyond the Bottom: The Nature of Bidding for a Firm, May 2010

3050 Xavier Vives, Competition and Stability in Banking, May 2010 
3051 Thomas Aronsson and Erkki Koskela, Redistributive Income Taxation under Outsourcing and Foreign Direct Investment, May 2010

3052 Michael Melvin and Duncan Shand, Active Currency Investing and Performance Benchmarks, May 2010

3053 Sören Blomquist and Laurent Simula, Marginal Deadweight Loss when the Income Tax is Nonlinear, May 2010

3054 Lukas Menkhoff, Carol L. Osler and Maik Schmeling, Limit-Order Submission Strategies under Asymmetric Information, May 2010

3055 M. Hashem Pesaran and Alexander Chudik, Econometric Analysis of High Dimensional VARs Featuring a Dominant Unit, May 2010

3056 Rabah Arezki and Frederick van der Ploeg, Do Natural Resources Depress Income Per Capita?, May 2010

3057 Joseph Plasmans and Ruslan Lukach, The Patterns of Inter-firm and Inter-industry Knowledge Flows in the Netherlands, May 2010

3058 Jenny E. Ligthart and Sebastian E. V. Werner, Has the Euro Affected the Choice of Invoicing Currency?, May 2010

3059 Håkan Selin, Marginal Tax Rates and Tax-Favoured Pension Savings of the SelfEmployed - Evidence from Sweden, May 2010

3060 Richard Cornes, Roger Hartley and Yuji Tamura, A New Approach to Solving Production-Appropriation Games with Many Heterogeneous Players, May 2010

3061 Ronald MacDonald and Flávio Vieira, A Panel Data Investigation of Real Exchange Rate Misalignment and Growth, May 2010

3062 Thomas Eichner and Rüdiger Pethig, Efficient Management of Insecure Fossil Fuel Imports through Taxing(!) Domestic Green Energy?, May 2010

3063 Vít Bubák, Evžen Kočenda and Filip Žikeš, Volatility Transmission in Emerging European Foreign Exchange Markets, May 2010

3064 Leonid V. Azarnert, Après nous le Déluge: Fertility and the Intensity of Struggle against Immigration, May 2010

3065 William E. Becker, William H. Greene and John J. Siegfried, Do Undergraduate Majors or Ph.D. Students Affect Faculty Size?, May 2010

3066 Johannes Becker, Strategic Trade Policy through the Tax System, May 2010 